\title{
分裂準備帯（preprophase band）と細胞分裂面の確立
}

\author{
峰雪芳宣 \\ 兵庫県立大学大学院生命理学研究科ピコバイオロジ一専攻 † 671-2280 兵庫県姫路市書写 2167
}

要旨：多細胞体制の生物の形づくりの研究には, 細胞分裂面挿入位置が時間的・空間的にどのように制御されているのかを 解明する必要がある。植物の細胞分裂面挿入位置は核分裂前に決定されており，その位置に分裂準備帯 (preprophase band) が 出現する. 著者は長年様々なイメージング技術を使って分裂準備帯の研究走行って来た. 本稿では，その成果を中心に分裂 準備帯の形成と機能について解説する.

\section{Preprophase band and division plane establishment}

\section{Yoshinobu Mineyuki}

Department of Picobiology, Graduate School of Life Science, Univ. of Hyogo, Shosha 2167, Himeji, Hyogo, 980-2280 Japan Author for correspondence: Y. Mineyuki, mineyuki@sci.u-hyogo.ac.jp

Summary: To elucidate the regulatory mechanism of division plane establishment is necessary for understanding the development of multicellular organism. In plant cells, the division site, the cortical region where cell plate fuses with the parental cell walls, is pre-determined before nuclear division and the preprophase band marks the site in prophase. Here, I review the research on the development and function of preprophase band based on historical background of our research.

Key words: preprophase band, plant division site, cortical division zone, division pattern, tomography

\section{はじめに}

植物の細胞は堅い細胞壁で囲まれているため，細胞分裂 の際に新しく形成された細胞壁が親の細胞壁とどの位置で 接続したかで娘細胞の将来の運命が大きく左右される。そ のため, ぞのようにして細胞分裂の際に細胞分裂面の挿入 位置が決定され，細胞板が挿入された後その場所がどのよ うに変化して行くのか, その制御機構を明らかにすること は植物の形態形成支考える上で重要である。図1 は才オム ラサキツユクサ雄しべの毛の細胞分裂過程を示している. オオムラサキッユクサ雄しべの毛は古くからライブイメー ジングでの植物細胞分裂研究の材料として知られており, 1880 年には細胞分裂の全過程を生きたまま追跡したスケッ チが記載されている (Strasburger 1880)。もつとも, Harris （1999）によれば，まだ細胞分裂の各過程が認識されていな かった 19 世紀半ばには，既に現在我々が知っているレ心゙ ルの正確さのスケッチ (Hofmeister 1849) が存在するようで ある。前期の細胞 (図 1A0) は, 核膜の崩壊と仁の消失がほ ぼ同時に起こり，前中期に入る(図1A13)。前中期に染色 体が徐々に赤道面に移動し，中期になる(図1A50)。図 1 の細胞では細胞の横の幅が狭いため, 中期の赤道面は斜め に入っている．後期に入り染色体が両極に移動を開始する （図1A51）と，最初斜めに傾いていた紡錘体が，徐々に染 色体の移動に伴って傾きを変更する(図 1 A $51 ６ 6$ ). 植物 の細胞分裂面は細胞板 (図 $1 \mathrm{~A} 78, \mathrm{cp}$ ) が細胞の中央に出現し, 遠心的に伸長することで挿入される (図 $1 \mathrm{~B}$ 上段) ため，植 物の細胞分裂面挿入位置 (division site) は, 最終的に細胞板 が親の細胞壁と接続する場所を指す (Gunning 1982)。この 場所がいつ，ぞのようにして決定されるかという問題に関 する最初の重要な発見は, 本学会会員の太田敬久博士によっ
てなされた．太田は分裂中のムラサキッユクサ雄しべの毛 の細胞の分裂装置を遠心処理により移動させる実験から， 植物の分裂面挿入位置は，少なくとも分裂中期以前に決定 しており, 分裂終期に出現する細胞板は, 細胞表層のその 位置(図 1A CDZ)に向かって伸張していくと結論づけた (Ôta 1961)。その 5 年後にPickett-Heaps と Northcote (1966a,b) が 電子顕微鏡観察で, 太田が指摘していた細胞表層の位置に 核分裂の前に存在する構造として分裂準備帯 (preprophase band; PPB) 在発見した. 実際には太田のCytologiaの論文は, PPB 発見後BusbyとGunning (1980) の論文で紹介されたこ とで再評価されることになった。

\section{分裂準備帯（PPB）と分裂面挿入位置（division site）}

PPB は核を取り巻くように細胞表層に並ぶ微小管の 帯 (図2)として認識され, 発見当時はpreprophase band of microtubules と表記されていた。しかし，PPBには微小管 以外にも小胞やアクチン, その他の分子が存在すること が分かり，1980 年代後半には微小管帯とその領域に存在 する分子打よび小胞なども含んだ構造としてPPB と呼ば れるようになつた。微小管以外の特定の分子を呼ぶ時には preprophase band of actinなどと呼ばれている.PPB発見後, $\mathrm{PPB}$ の位置と細胞板挿入位置とが一致することが様々なタ イプの細胞で確認された。しかし，大部分の細胞分裂では PPBの存在した面は細胞板だけでなく中期の赤道面とも一 致するため, PPB は分裂面を決めるのか赤道面を決めるの か問題が残った. Palevitz と Hepler（1974）は，分裂面が赤 道面と $45^{\circ}$ 異なる方向に挿入されることが知られていた夕 マネギ孔辺母細胞の観察から, PPBが赤道面ではなく分裂 面を予言することを証明した (図 $3 \mathrm{~A}(\mathrm{e}), \mathrm{B}(\mathrm{d})$ - (h) )。赤道 
面と分裂面の方向が一致しない現象は, 孔辺母細胞に特異 的なものというわけではなく, 図1の様にオオムラサキッ ユクサ雄しべの毛の細胞分裂でも観察できる. PPBは陸上 植物でしか観察されず, 陸上植物でもコケの原系体なぞ 細胞分裂によってはPPBが出現しないものもある。また,
被子植物でも減数分裂や一部の生殖に関連した細胞分裂 でPPBが存在しないことが知られている (Mineyuki 1999). PPB は陸上植物の体細胞分裂で発達した細胞分裂面の位 置を決める細胞質分裂装置と考えられる.

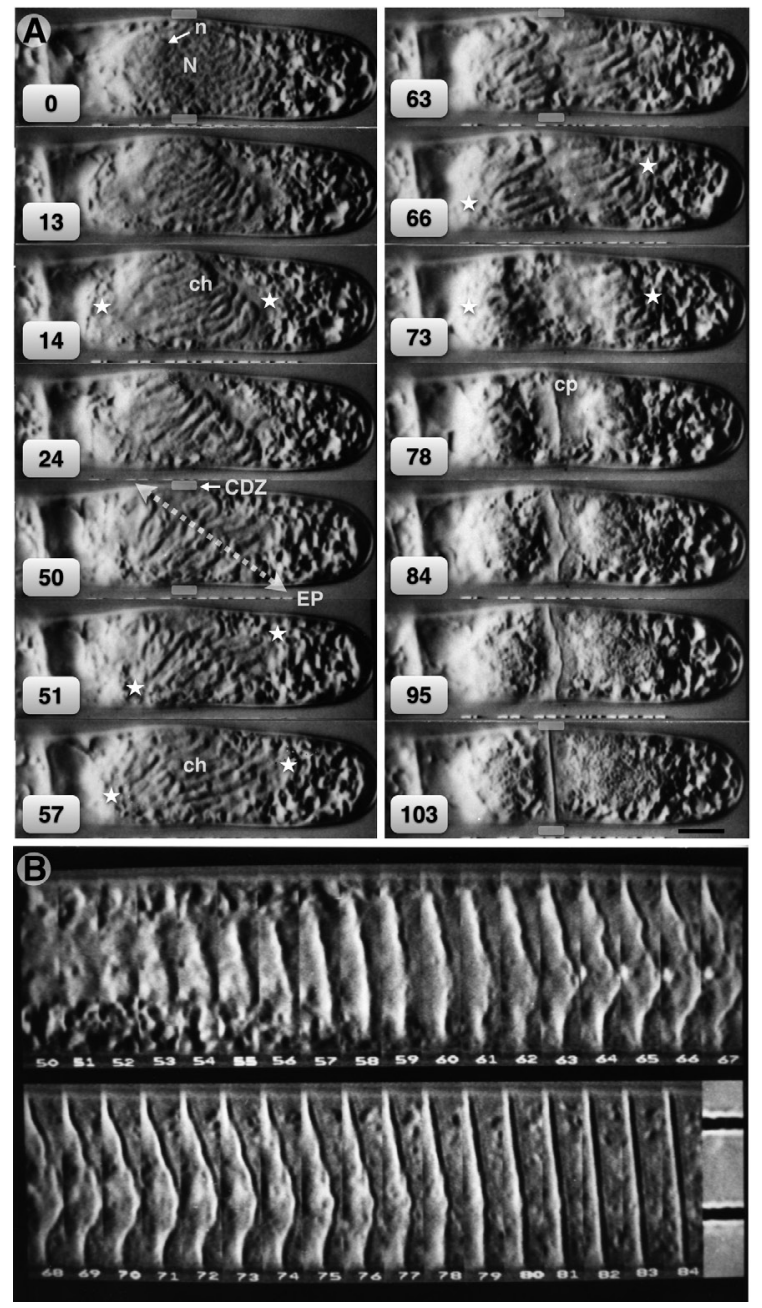

図 1 オオムラサキッユクサ雄しべの毛の細胞分裂のライブイメージング像. (A) 高感度微分干渉顕微鏡によるタイムラプスVTR撮影法 (Mineyuki and Gunning 1988）で撮影した細胞分裂前期から細胞板形成直後までの 103 分の 様子左上から右下へ経時的に並べている. 各細胞の左下の数字は, 左上の 細胞を 0 分とした時の相対的な時間を示す. 0 分は前期, $13 \sim 24$ 分は前中期, 50 分は中期, $51 \sim 66$ 分は後期, $73 \sim 78$ 分は終期, $84 \sim 103$ 分は細胞板接着 後の像である. 50 分目の細胞中に斜めに示した矢印は赤道面 (EP) の方向を, 灰色横棒は表層分裂面挿入予定域 (CDZ) 在示す。この細胞では赤道面と分 裂面挿入位置が異なっていることが分かる。後期〜終期の細胞に付けた次印 は移動中の分裂装置の極の位置走示す. 徐々に方向が変化していることがわ かる. ch, 染色体 ; cp, 細胞板 ; N, 核 ; n, 仁. 右段下 $\mathrm{Bar}=10 \mu \mathrm{m}$. (B) 細胞 板形成々細胞板成熟過程. 細胞板が細胞中央に出現した地点 ( (B) 上段左端 50) から 1 分拈きに細胞板の部分を並べたキモグラム. 下の数字は時間 (分) を示す.（A）の数字から 21 引いた值になっている. Mineyuki and Gunning (1990)より許可を得て転載. Mineyuki and Gunning (1988) が Image-I (現在の Metamorph)用に開発したりフトを使用. 論文ではstreak photo となっているが, Image-I のコマンドに採用された時に kimograph というコマンドになった。 下 段右端に $10 \mu \mathrm{m}$ 間隔のスケールバーを示している.
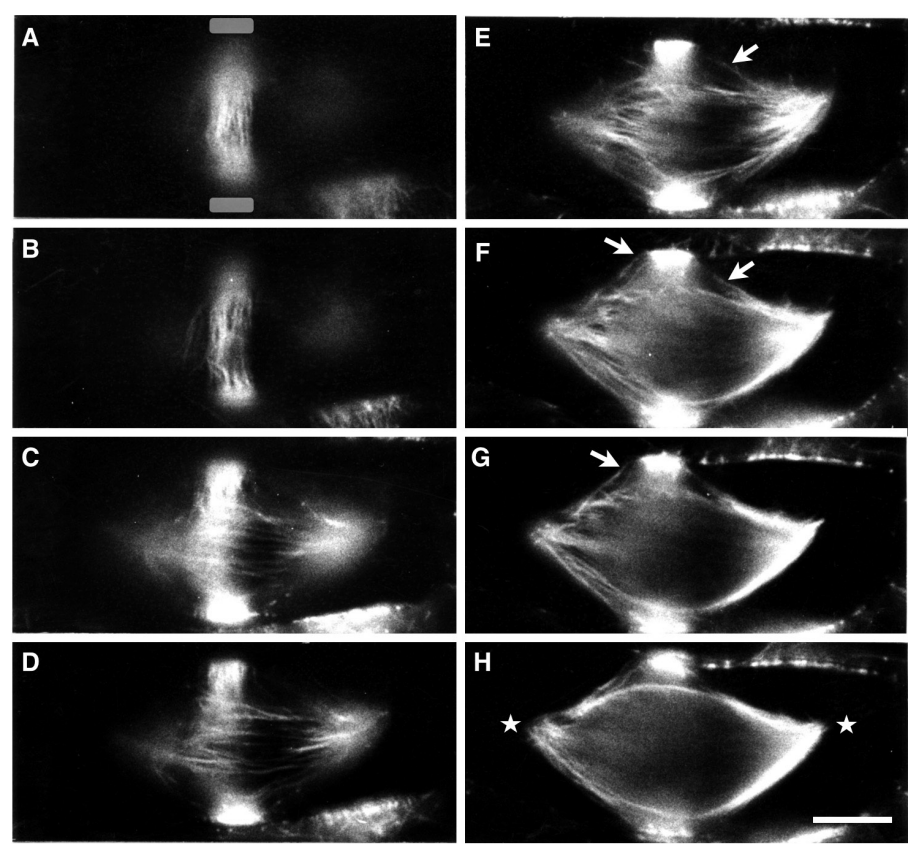

図2 タマネギ子葉皮層細胞の分裂準備帯 $(\mathrm{PPB}) .(\mathrm{A}) \sim(\mathrm{H})$ は同一細胞の異なる光学切片走示す. 間接蛍光抗体法で微小 管を染色し, 蛍光顕微鏡死使って細胞表層から中央部まで, 焦 点を手動でずらしながらフィルムで撮影. 共焦点レーザー顕微 鏡ではないので, $z$-軸方向の間隔は正確でない. 図には核の状 態を示していないが, この細胞は前期後半の時期で, 幅の狭い PPB ( (A) の灰色の横棒) と前期の紡錘体 (污印は紡錘体の極の 位置を示す)が共存している. 紡鍾体の極近傍から PPBに向かっ て走る微小管 (矢印)が存在する. この時期 PPB と紡錘体は垂直 に位置するため, PPBの一つの役割として前期の紡錘体の位置 在保つ働きが考えられている. Mineyuki et al. (1991a) t改変. $\mathrm{Bar}=10 \mu \mathrm{m}$. 


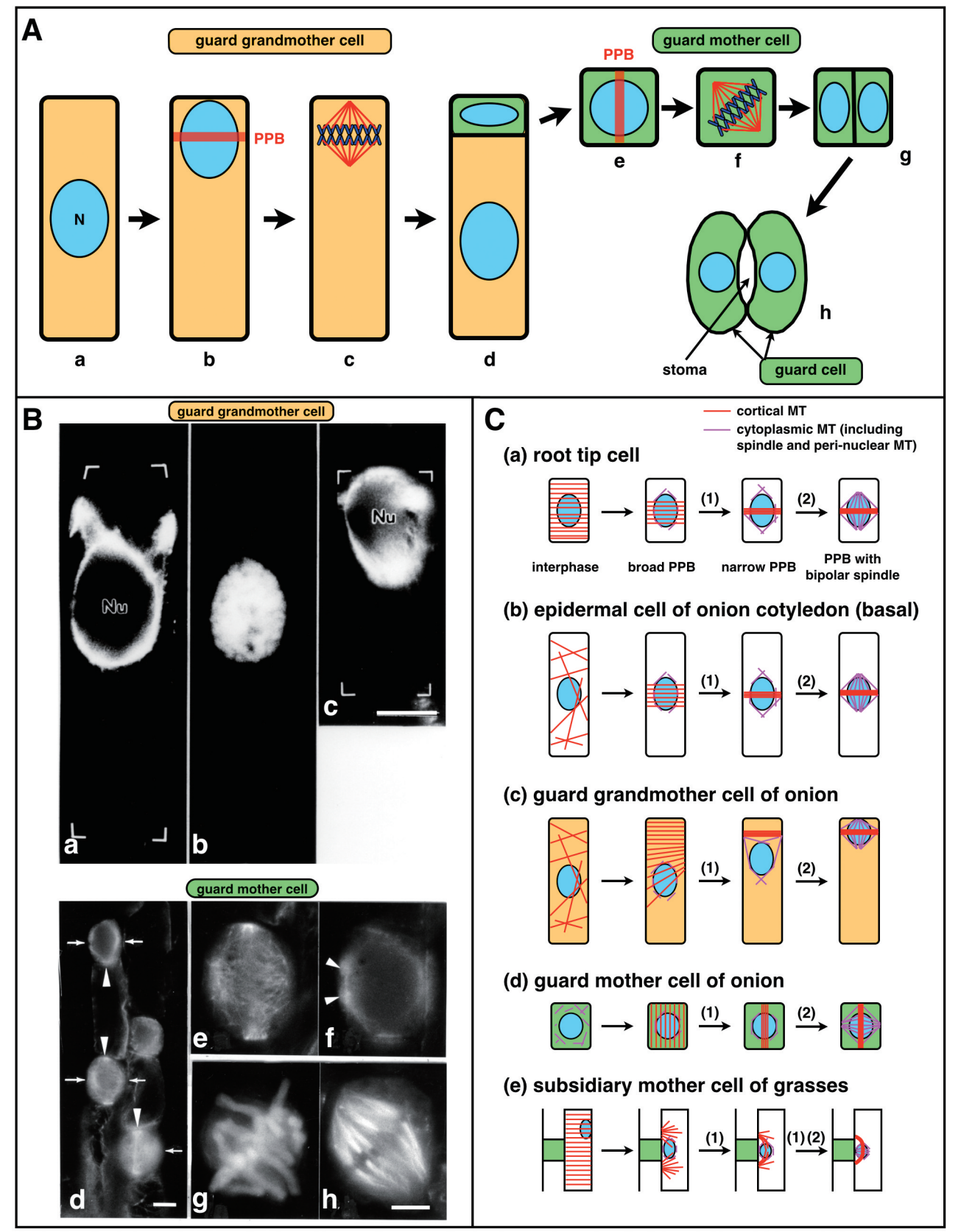

図3 気孔分化の細胞分裂パターンとPPB. 細胞の図, 写真はすべてページ下が子葉の基部になるように配置している. 緑, 孔辺母細胞 (guard mother cell) と孔辺細胞 (guard cell) ; 黄土色, 孔辺母細胞を造る不等分裂を行う細胞 (guard grandmother cell); 水色, 核打よび染色体; 赤, 微小 管.

（A）タマネギ子葉表皮の気孔分化過程の模式図．（a-d）孔辺母細胞支造る不等分裂．（a）間期，(b) 前期後半，(c) 中期，(d) 細胞分裂直後.（e-g） 孔辺母細胞の分裂, (e) 前期, (f) 中期, ( g) 細胞分裂直後, (h) 気孔.

（B）タマネギ子葉表皮の気孔分化過程で見られる PPB. 蛍光抗体法 (貼り付け法) による微小管染色 ( a, c, d, e, f, h) と HoechestによるDNA染色 (b, g). (a-c) 孔辺母細胞を造る不等分裂の PPB. (a, b ) 核移動前の前期細胞. (a) と（b) は同じ細胞. 核が移動する前にPPBが先端よりにできている. (c) 核移動後の PPB. $\mathrm{Nu}$ は核の位置走示す. Mineyuki (1999) より許可起得て掲載. Bar $=10 \mu \mathrm{m}$. (d-h) 孔辺母細胞の PPB と中期の染色体. (d) 3 つの前期細胞が並んでいるのが観察できる. 矢印, 紡鍾体の極 ; 鏃, PPB. Bar $=10 \mu \mathrm{m} .(\mathrm{e}, \mathrm{f})$ 前期の PPB. (d) 中の 1 個の細胞の拡大とその細 胞の異なる光学平面. 鏃, 極 (この紡鍾体の極は微小管は 1 点に収斂せず, 典型的な極帽 (polar cap) になっている). ( $\mathrm{g}, \mathrm{h})$ 中期の染色体 (g) と 紡鍾体 (h). Mineyuki et al. (1988a) より許可支得て掲載. Bar $=10 \mu \mathrm{m}$.

孔辺母細胞を造る不等分裂を行う予定の細胞では, 間期にPPB形成が開始し, 前期に幅狭いPPBが細胞の先端近くに形成されると核が移動 を開始しする $(\mathrm{B}(\mathrm{a}),(\mathrm{b}))$ 。前期の核が先端に到着する $(\mathrm{A}(\mathrm{b}), \mathrm{B}(\mathrm{c}))$ と, 核分裂が開始し横方向へ細胞分裂面が挿入され，先端に小さな孔辺母 細胞が形成される不等分裂が完了する $(\mathrm{A}(\mathrm{d}))$. この不等分裂では, 中期の赤道面 (A ( $\mathrm{c}))$ も分裂面と同じ場所に位置する. 孔辺母細胞の前期 に出現する PPB は縦方向に並ぶが $(\mathrm{A}(\mathrm{e}), \mathrm{B}(\mathrm{d}),(\mathrm{e}))$, 中期の赤道面は斜め方向に並ぶ $(\mathrm{A}(\mathrm{f}), \mathrm{B}(\mathrm{g}),(\mathrm{h}))$. しかし, 最終的な分裂面は縦方向 に挿入される $(\mathrm{A}(\mathrm{g}))$.

(C) 様々な分裂タイプにおけるPPB形成時の微小管配列の変化を示す模式図. 水色, 核 ; 赤, 表層微小管 ; 赤紫, 細胞質微小管 (核表面沶 よび紡鍾体の微小管も含む)。(a)，根端分裂組織細胞 (Wick and Duniec 1983, 1984, Mineyuki et al. 1988b). (b), タマネギ子葉表皮基部の等分 裂 (Mineyuki and Palevitz 1990). (c) タマネギ子葉表皮の不等分裂 (Mineyuki and Palevitz 1990). (d) タマネギ子葉表皮基部の孔辺細胞母細胞 の分裂 (Mineyuki et al. 1989). (e) イネ，オオムギ，トウモロコシなどに見られる助細胞を形成のための不等分裂 (Cho and Wick 1989, Cleary and Hardham 1989, Mullinax and Palevitz 1989).（1）微小管帯が狭くなる素過程；(2)PPB と垂直に2極性の紡釺体在形成する素過程. 


\section{PPB 形成時期と細胞周期}

PPB は Jeremy H. Pickett-Heaps (図 4A) が大学院生の時 に発見したものである. 電子顕微鏡の超薄切片では染色 体の凝集具合で前期核かどうか判定がしばしば難しい. Pickett-Heaps そ Northcote (1966a) は, PPB微小管を持つ細 胞は前期と間期の移行期に分裂準備を開始するための形態 変化の現れる時期と考元, その時期を “preprophase” と名 付けた. Pickett-Heapsはこの時期を特徴づけるために, 染 色体の状態, 仁の形状, およびPPB微小管の有無起使う ことを提唱したが (1969), 前者2つでの定義づけには問 題が残つた. PPB 持つ細胞の核の状態の判定の問題か ら, “preprophase” は前期なのか，その前の間期なのか，そ れとも間期から前期の一部を含むのか議論が続き, PPB を prophase band (PPBは前期のみに存在するとの主張), preprophase-prophase band, interphase-mitosis transition band 等と呼び換える案も提唱されていた(詳細は峰雪 (1997) 参 照). この問題は, 根端分裂組織細胞の微小管を蛍光抗体

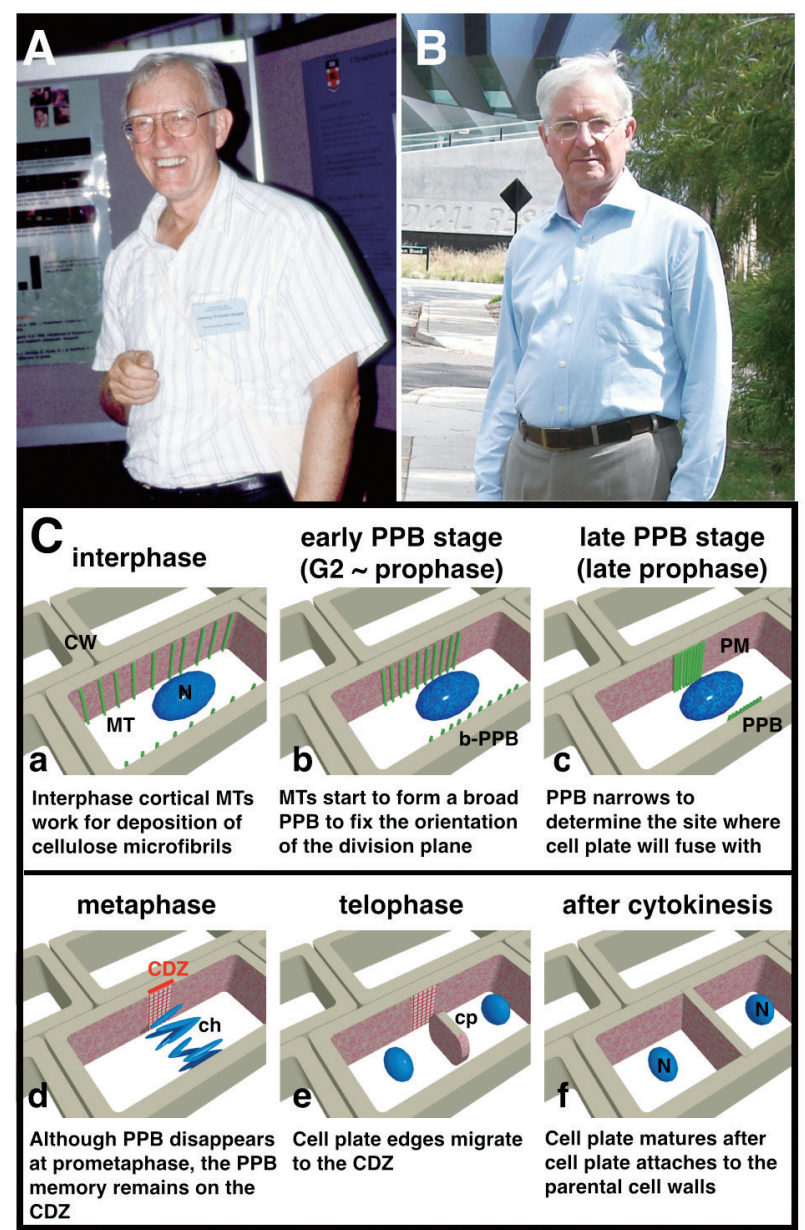

図4 初期のPPB 研究に貢献した人物とPPB形成とその機能を示す モデル. (A) Jeremy H. Pickett-Heaps博士. (B) Brien E. S. Gunning 博士. (C) PPBの成長, CDZ形成とその役割. (a) 間期には表層微 小管に沿ってセルロースのミクロフィブリルの沈着が起こる. (b) G2 から前期にPPB が幅広微小管帯として出現し, この微小管帯の配向 した方向に将来の分裂面挿入方向が決定する. (c) 前期にかけて微 小管帯の幅が徐々に狭くなり, 将来細胞板が接着する予定域になる CDZが形成される. (d) 前中期に微小管帯が消失するが, CDZはそ のまま残る. (e) 終期に出現する細胞板は CDZに向かって伸張する. (f) 細胞板が $\mathrm{CDZ}$ のに゙こか $(\mathrm{CDS})$ で接続後, 細胞板の成熟が完成する. Karahara et al. (2012) 改変.
法で染色し，核の蛍光染色との比較することで解決した。 Wick ら (Wick and Duniec 1983, 1984, Mineyuki et al. 1988b) の一連のタマネギ根端分裂組織細胞の観察から, PPBは間 期にも存在すること, また, 前中期に消失することが判明し, 現在では“preprophase”は細胞周期の特定の時期 (“前期の前” など）を表すのではなく, 細胞質に PPBなど細胞分裂の準 備と思われる構造が出現している時期, つまり PPB を持つ 細胞では間期のある時期から前期の終わりまでを指すよう になっている (Mineyuki 1999).

PPBが細胞周期のどの時期に出現するのか, この問題に 関して初期の電子顕微鏡時代に, G2 期頃に徐々に核の周 辺に微小管が集まり始めること示した報告がある。これ は細胞周期を同調的に進行させたホウライシダ原糸体の表 層微小管分布の定量的解析によるものである (図 5, Wada et al. 1980). この研究は著者の最初の研究で, Lyndon （1990）の教科書に引用してもらつている．その後著者は Brian E. S. Gunning (図4B) の研究室に移り, タマネギ根端 分裂組織細胞の PPB 老持つ核の DNA 量の定量的な解析か ら，PPBはG2期に出現すること支明らかにした (Mineyuki et al. 1988b). 根端分裂組織細胞ではDNA 合成が終了して 間もない時期にPPB微小管の形成を開始する細胞も存在 するが (Gunning and Summut 1990), G2 期の細胞の半数以 上はPPB微小管の形成を開始していない (Mineyuki et al. 1988b)。また, 薬剤でDNA 合成を停止させ, その後薬剤 を除去して細胞分裂を同調的に誘導すると, PPB微小管 の出現頻度が上昇すること (Burgess and Northcote 1969) か ら, PPBも同調的に誘導できていると思わ机る.しかし，

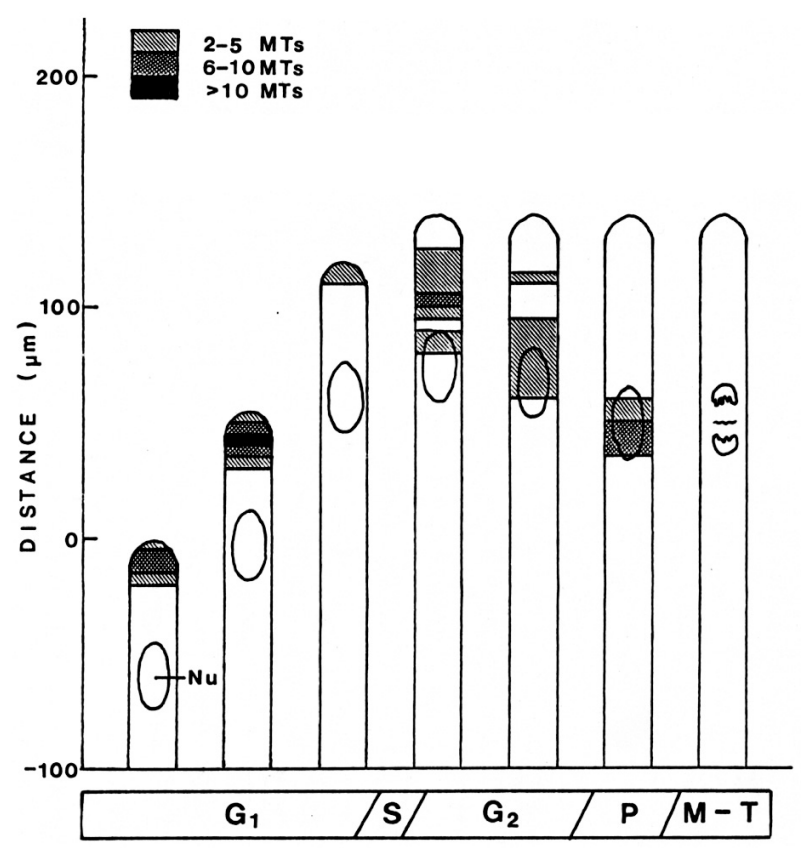

図 5 ホウライシダ原糸体の細胞周期進行に伴う表層微小管分布の 変化. 赤色光下で核周期が $\mathrm{G} 1$ 期に停止した状態で先端成長を行っ ている原糸体を暗所に移すことで細胞分裂を同調的に誘導した。下 に細胞周期の各時期を示している. 細胞周期の進行開始した時点で の先端の位置を 0 として, その後の平均的な原糸体の成長走考慮し て各時期の原糸体を並べている. Nu, 核の位置; 斜線で囲った部分, 表層微小管が存在している部分. 斜線の密度が浱いほぞ微小管の数 が多い領域支示す. G2 期から徐々に核の周りに微小管が集まり始め る (Wada et al. 1980). 
DNA 合成阻害剤存在下では $\mathrm{S}$ 期の細胞で PPB微小管を持 つ細胞が出現することから, 初期の PPBの微小管帯形成 進行と核周期進行とは部分的に脱共役可能であると考え られる (Mineyuki et al. 1988b)。一方，前期になるとPPB にcdc2 (CDKA) が局在し (Mineyuki 1991b, Colasanti et al. 1993), cdc2 の活性が上昇することで核膜崩壊とほぼ同時 に微小管帯は消失する (Hush et al. 1996).

微小管帯形成の2つの素過程 : 分裂面の方向と位置の決定

根端分裂細胞ではPPBは最初幅の広い微小管帯として 出現し, 前期の進行に伴って徐々に微小管帯の幅が狭くな り, 前期の最後では幅の狭い微小管帯々前期の紡錘体が共 存する (図 $3 \mathrm{C}(\mathrm{a}))$. 多くの根端分裂組織細胞では, 間期の 細胞の伸長方向を制御する間期表層微小管と PPB微小管 の方向が同じであるが，幅広微小管帯の出現と同時に核膜 周辺に微小管が出現すること（Wick and Duniec 1983），ま た，シクロへキシミドでタンパク質合成を阻害すると間期 表層微小管は 2 時間以内に表層から離れるのに対し, PPB 微小管はそのまま表層に残ることで区別することができる (Mineyuki et al. 1994). しかし, 将来の分裂面の方向に間 期微小管も並んでいるため, いつ分裂面が決まるかの研究 には適していなかった。

気孔の分化過程は細胞分裂のパターンが正確にプログラ 厶されて行われ, 途中で分裂面の方向も変更するため (図 $3 \mathrm{~A})$, 分裂面の方向の決定と PPB 形成の過程の研究に適し ている。しかし，この研究には細胞の並びを残したまま蛍 光抗体染色する必要がある。細胞表層支瞬間接着剤で貼り 付け, 内側の細胞を除いて表皮の細胞を観察する方法 (貼 り付け法) がMarc と Hackett (1989) により開発され, 気孔 分化過程でのPPB形成の研究が可能になった. 図 $3 \mathrm{C}$ は様々 なタイプの細胞分裂における微小管帯形成過程をまとめた ものである. タマネギ子葉表皮, 特に基部の部分では, 表 皮細胞を造る等分裂の場合 (図3C (b)) でも, 孔辺母細胞 起造る不等分裂の場合 (図3B (a) - (c), C (c) ) でも, 間期表 層微小管はあまり横方向に並んでおらず，むしろランダム である。これらの細胞では, 表層微小管が横方向 (将来の 分裂面の方向) に並び始めるのは, 幅広 PPB出現時である. 孔辺母細胞の分裂では, その分裂面は前の不等分裂と $90^{\circ}$ 異なる方向に挿入される (図 $3 \mathrm{~A}(\mathrm{~d}),(\mathrm{g}))$. 前の不等分裂終 了後の間期細胞では, 微小管は細胞質に多く表層には少な い。この細胞の微小管が表層に並び始めるのはやはり幅広 PPBが出現する時である (図 $3 \mathrm{C}(\mathrm{d})$ )。我々はこれらの観察 老元に, PPB形成過程は2つの素過程に分かれ, まず幅広 PPB形成過程で将来の分裂面の方向を決定し, 微小管帯が 狭くなる過程で幅数 $\mu \mathrm{m}$ の細胞分裂面挿入位置が決まると いう考え老提唱した (Mineyuki et al. 1989, Mineyuki 1999). 穀類の気孔では助細胞があり, 複雑な形の PPBができる (図 3C (e)) が，この形成過程もこの考えで説明がつく(Mineyuki 1999). タマネギ子葉表皮の分裂では, アクチン毒のサイ トカラシンが細胞周期進行は阻害しないが微小管帯の幅 が狭くなる過程を阻害する (Mineyuki and Palevitz 1990). Nautilocalyx の葉の基部の外植片の細胞分裂では, 培養開 始して数日で切り口に平行に細胞板が挿入される。 PPB 形成開始時期より前にこの組織片圭傷口と垂直な方向に傷 口を入れると, 分裂面は新しい傷口と平行な方向に挿入
される。しかし，PPB形成が開始した時期以降に新しい傷 口を入れても分裂面の方向は変化しない (Venverloo 1990). これは, PPB形成初期に将来の分裂面の方向が決定すると いう考えを強く支持する実験結果である.

\section{PPB形成と表層分裂面挿入予定域（CDZ）}

PPB 微小管は前中期には消失し，その位置には見かけ上 何もないように見える。しかし, 細胞板は正しくその位置 を認識して伸長していくことから, PPBが存在している間 にその場所になんらかの位置メモリーを残す働きがあると 考えられる. 一方, 親の細胞壁に到達して間もない細胞板 は湾曲しているが, やがて真つ直ぐな細胞壁に変化する(図 1A84-103, B下段)。この細胞壁の成熟は, 遠心処理や薬剤 処理を使って実験的に細胞板がPPBの存在していた位置に 到達できない，あるいは接続できないようにした場合には 進行が遅れる (Mineyuki and Gunning 1990)。これらの事実 を元に Mineyuki と Gunning (1990)はPPB形成過程でPPB の 存在する場所近傍に細胞板を PPBの存在していた位置に誘 導するための位置メモリーとして働く因子と親の細胞壁に 接着した細胞板の成熟に関与する因子が蓄えられるという 仮説起提唱した (図4C).

位置メモリ一候補として最初に見つかつたのはアクチン であった.アクチンはPPBに存在する分子として知られて いたが(後の章で述べる), PPB微小管が消失する少し前の 時期から, アクチンはPPBの領域支除く細胞全体に分布し, PPB 領域から排除されるようになる。このアクチン排除域 は微小管帯消失後も残っているので, ネガティブメモリー としての働きが考えられる (Liu and Palevitz 1992, Cleary et al. 1992). 同様の分子としてキネシン様タンパク質KCA1 (Vanstraelen et al. 2006) も発見された. 一方, ポジティブ メモリ一候補の分子として動物の APCタンパク質の微小 管結合部位を有するタンパク質TAN (Walker et al. 2007) や RanGTPase活性化タンパク質 $\operatorname{RanGAP}(\mathrm{Xu}$ et al. 2008) なぞ が発見されている。また, 細胞板成熟に関係する候補の 分子としてAdaptin様タンパク質TPLATE (Van Damme et al. 2006), 微小管付随タンパク質AIR9 (Buschmann et al. 2006)などが報告されている.

PPB が標識する細胞表層は数 $\mu \mathrm{m}$ の幅の領域なのに対し, 実際の細胞板の幅はその 10 分の 1 程度なので, 最近の研 究では前者を表層分裂面插入予定域 (cortical division zone; CDZ) と呼び, 最終的に細胞板が接着した細胞表層の位置 (cortical division site) と区別する様になった（Van Damme et al. 2010). 図4C は現在考元られているPPBの形成と機能 を模式図で表したものである。幅広PPBが出現する過程 で将来の細胞分裂面の方向が固定され(図4C (b)), やが てPPBの幅が狭くなって, PPBが局在する細胞表層がなん らかの特殊な修飾を受け, CDZが形成される(図 $4 \mathrm{C}(\mathrm{c}))$. 微小管は核膜消失と共に CDZ から離れるが, CDZ (ポジ ティブメモリ一候補と言われている分子が局在し，六ガ ティブメモリ一候補の分子が排除される性質を持った細胞 表層の帯状の領域) はそのまま残り（図4C (d)), 終期に細 胞板を CDZに誘導する (図 $4 \mathrm{C}(\mathrm{e})$ ). 細胞板が親の細胞壁 に近づくと, 別の分子群がその位置に集まりその後の細胞 板の成熟に関与していると考えられる(図4C (e)). 現在, これらの分子機作の研究が進行している (Duroc et al. 2011, 
Rasmussen et al. 2013).

微小管帯の形成には TONNEAU1 (TON1, Azimzadeh et al. 2008), FASS/TON2/DCD1/ADD1 (Trass et al. 1995, McClinton and Sung 1997, Camilleri et al. 2002, Wright et al. 2009), SABRE, CLASP (Pietra et al. 2013) が関与している. また, FASS/TON2 と TON1 はタンパク質脱リン酸化酵素 PP2A 複合体として㗢いているようである (Spinner et al. 2013). PPB形成が進むと, TANや2種のクラス 12 キネシ ン POK1, POK2 などが集まって CDZを形成する (Müller et al. 2006)。POK1/POK2 が終期に細胞板の端を CDZに導く のに関与する可能性も考えられている (Lipka et al. 2014). 最近, 終期の細胞板の誘導には微小管端に存在するミオシ ンVIIIが関与しているという報告もある(Wu and Bezanilla 2014). 今後の検証が必要であろう.

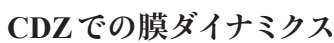

前章でも述べたようにCDZ形成過程で様々な分子の挙 動が明らかになってきている。しかし, 蛍光プローブを使つ た光学顕微鏡での観察では, 実際の分子間の相互作用に関 しての情報には限界がある。そのため, 電子顕微鏡レベル での $3 \mathrm{D}$ 観察が必要であった. 我々は 10 年以上前から PPB の構造を 3Dで解析するために, タマネギ子葉を加圧凍結 ／凍結置換し(峰雪ら 2001), それを使つて電子線卜モグ ラフィー法 (峰雪ら 2004) でPPB 䚈察している。この 方法により幾つかの新しい事が見つかってきた。電子線 トモグラフィー法とは, 比較的厚く切った切片を $-60^{\circ}$ から $+60^{\circ}$ まで傾斜画像走取得し，それをコンピュータートモ グラフィー $(\mathrm{CT})$ の方法を使って計算し立体再構成する方 法である. 図6はタマネギ子葉基部細胞の前期後半の時期 の PPB (図 $3 \mathrm{C}$ (b) の右端の細胞に相当する) の電子線卜モグ ラフィ一像の 1 例である. 連続傾斜画像を元に計算し立体 再構成したデータ(これをトモグラムと呼ぶ) から一つの 平面を抽出して示したものである。図6 A は細胞膜のすぐ 内側の PPB領域を示している. 実際の一つのトモグラムで は, このような平面 ( $\mathrm{x}-\mathrm{y}$ 平面) が $\mathrm{z}$ 軸方向に 100 枚以上重なっ た形になっている。この方法では被覆小胞 (図6B), 微小 管 (図7B)，マイクロフィラメント(図8B) などが明確に判 定できる。また，一つのトモグラムの中には多数のこれら の小胞や細胞骨格が存在するので, その出現頻度の比較検 討も可能である.

我々の研究以前に 1 枚の有名な電子顕微鏡写真があつた. それはPackerd とStack (1976)の論文で, PPBの近傍にゴル ジ体が存在し, ゴルジ小胞と似た小胞が細胞膜と融合し ている写真である。この写真から，PPBに蓄積されるメモ リーはエクソサイトーシスで細胞膜の外に蓄積されると考 えられてきた．実際, Mineyuki と Gunningのモデル (1990) も，それを踏襲していた。 しかし，我々の電子線卜モグラ フィーの結果 (図6) は, PPBに存在する小胞はゴルジ由来 のエクソサイトーシスを行う小胞ではなく, エンドサイ トーシスを行うクラスリン被覆小胞であることが分かった (Karahara et al. 2009). 被覆小胞でない非被覆小胞 (図6C) も存在するが, その分布が被覆小胞よりもより細胞質側に 多く分布することと2つの中間的な小胞も存在することか ら, 非被覆小胞は被覆小胞の被覆が外れたものと考えられ る (Karahara et al. 2009, 2012). また, この小胞の出現頻度

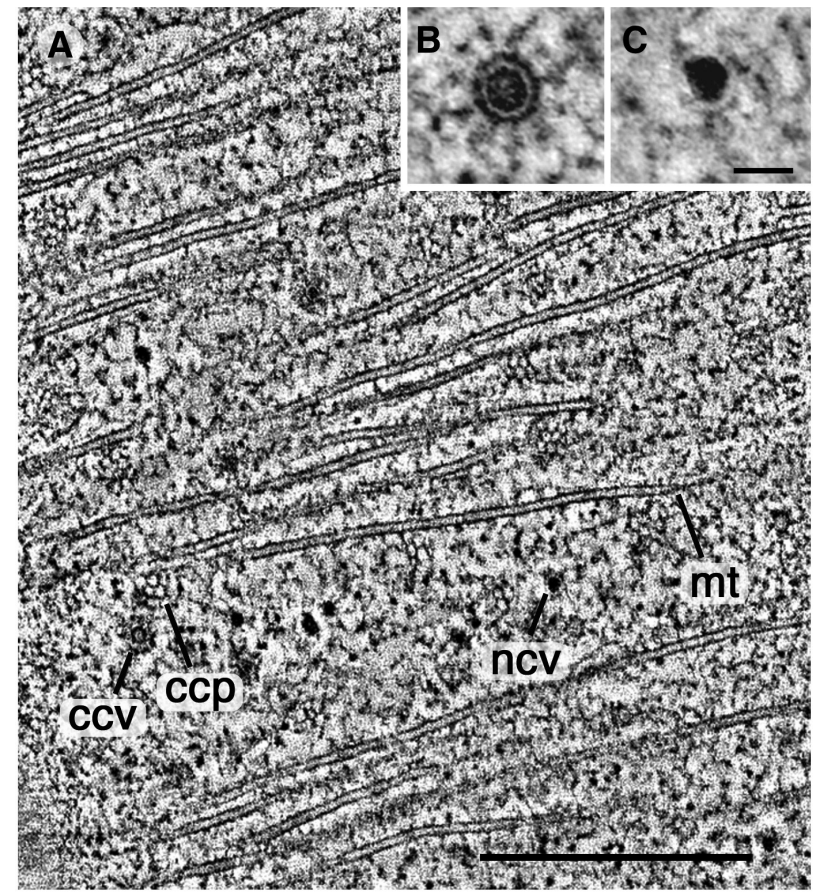

図6 タマネギ子葉表皮 PPB の電子線卜モグラフィー像. (A) トモグ ラムから子葉接線面方向に切り出した細胞表層 $1.42 \mathrm{~nm}$ 厚の切片像. 1 個のトモグラムは, このような切片像が約 110 枚集まってできている. 試料は加圧凍結/凍結置換法により作製. $250 \mathrm{~nm}$ 厚の切片から卜モ グラムを作製した。 ccp, 被覆ピット; $\mathrm{ccv}$, 被覆小胞； $\mathrm{mt}$, 微小管； $\mathrm{ncv}$, 非被覆小胞. $\mathrm{Bar}=1 \mu \mathrm{m}$. (B), (C) トモグラムの一部から抽出 した被覆小胞 $(\mathrm{B})$ と非被覆小胞 $(\mathrm{C})$ の像. Bar $=50 \mathrm{~nm}$. Karahara et al. 2009 在改変.

をPPB と PPB外, あるいは間期の細胞表層とで定量的に 比較した結果, $\mathrm{PPB}$ の最後の時期にはPPB近傍にクラスリ ン小胞が増大し PPB領域, つまり CDZで, エンドサイトー シスが活発なことが分かった (Karahara et al. 2009). 我々 はエンドサイトーシスでPPB領域の細胞膜が細胞質に回収 される時に, 細胞表層に存在している特定の因子, 例えば F-アクチン重合因子が一緒に回収されアクチン排除域が形 成されるのではないかと考えている (Karahara et al. 2010).

PPB形成過程での微小管束化における F-アクチンの役割

PPB形成過程でに゙のようにして微小管は CDZ に集まる のであろうか? 蛍光プローブを使つたライブイメージング による微小管ダイナミクスの解析から, PPB形成時期の微 小管は間期よりもダイナミックな性質を持つ可能性が示さ れている (Hush et al. 1994, Dhonunkshe and Gadella Jr 2003, Vos et al. 2004). しかし, 微小管帯のパックされた部分で の解析は難しいなどの問題があった. 峰雪は微小管帯が狭 くなる過程で微小管が束化していくと考えている(1999). 図7A はタマネギ根端分裂組織細胞のPPB 発達過程での隣 り合う微小管と微小管の距離の変化を示したものであるが, 幅狭微小管帯になると微小管の数が増すだけでなく, 微 小管間の距離も小さくなっていることがわかる (Nogami et al. 1996). 電子線トモグラフィーで実際にPPB成長過程で 微小管の束化の様子を追跡すると, 最初は数本の微小管が 架橋構造によって束になり, それが幅広く分布しているが, 徐々にこれらの微小管束が集合し大きな微小管束のクラス 
ターを形成し, 最後は数個の微小管束のクラスターになる ことが分かった (Takeuchi ら 未発表)。また, 電子線卜 モグラフィーでは重合していると思われる微小管端 (図7B (a)), 脱重合していると思わ犼る微小管端 (図7B (c)), $\gamma$ チューブリン複合体でキャップされていると思われるマイ ナス端 (図7B (d)) なぞが明確に区別でき, 間期の表層微小 管と PPB 微小管でこれらの微小管端の出現頻度を比べると, $\mathrm{PPB}$ 微小管が間期よりもよりダイナミックに重合, 脱重合 していることがわかる。

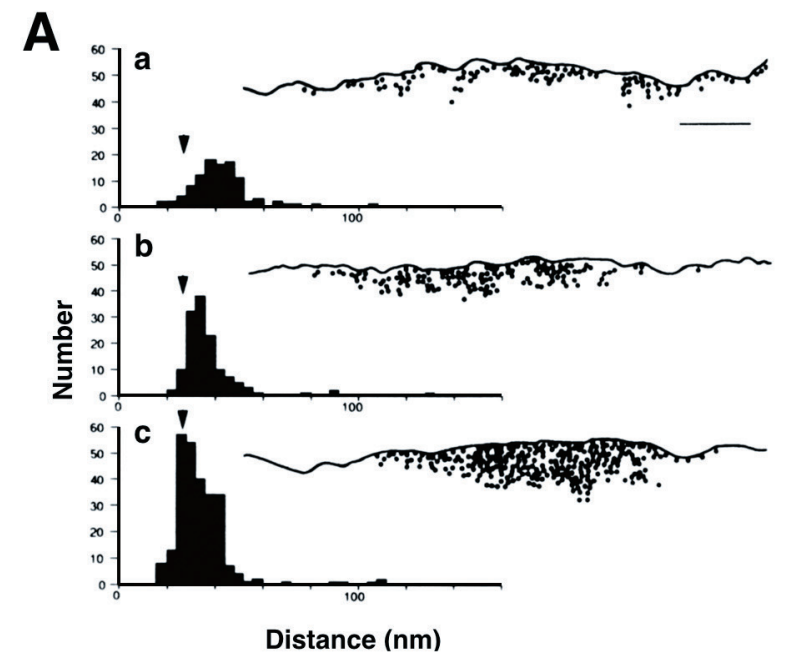

\section{B}

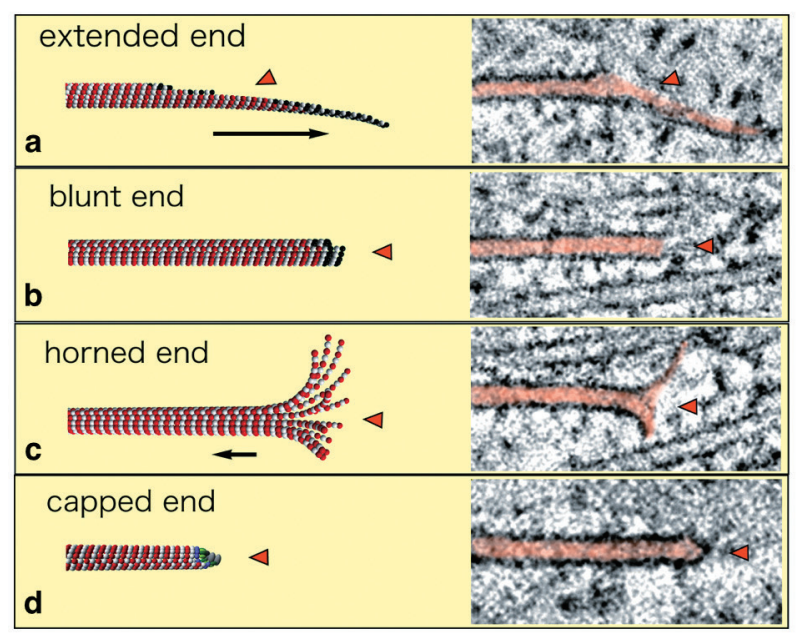

図7 電子顕微鏡によるタマネギPPB微小管の解析. (A) グルタル アルデヒドとオスミニウム酸による化学固定した根端分裂組織細胞 のPPB 発達過程における微小管分布の変化. 図右上はPPBの横断 面を示し, 点は微小管を, 横に引いた曲線は細胞膜を表す。図左下 は各ステージでの隣り合う微小管間の距離の頻度を示すヒストグラム。 (a) から (c) に移行するに従ってPPB は徐々に成長し, 典型的な幅狭 PPB t形成する. ヒストグラムに示した矢印は幅狭PPBの最も出現頻 度が高かつた微小管間の距離を示す. 横軸の微小管間の距離は, 微 小管の中心から隣の微小管の中心までの距離を示している. PPBが 成熟するに従って微小管の数が増え, 微小管間の間隔も狭くなつて いる.（a）右 Bar $=500 \mathrm{~nm}$. Nogami et al.（1996）在改変．（B）子葉表 皮細胞の電子線卜モグラフィーのデータから抽出した代表的な微小 管端の構造 (右) とそのモデル (左).（a）シート状に開いた微小管端. 伸張端と思われる構造. (b) 平坦な微小管端. (c) 反り返つた微小管端. チューブリンが脱重合していると考えられる. 矢印は微小管が短縮し ていく方向. (d) キャップ端. $\gamma$ チューブリン複合体でキャップされた マイナス端. 峰雪ら (2004) 在改変.
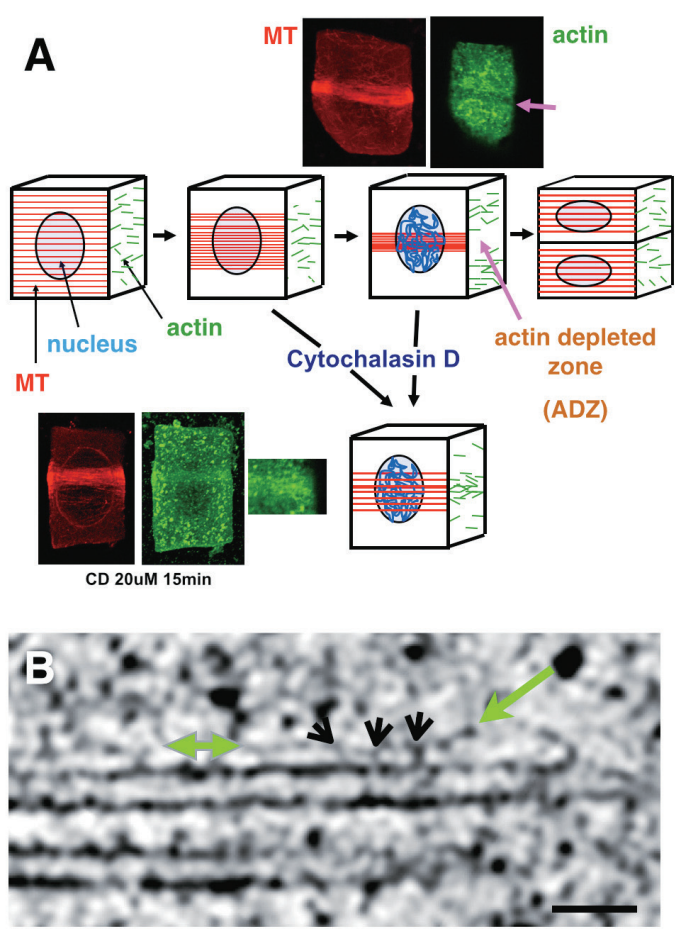

C

(a) Contact of a F-actin along a MT to another MT

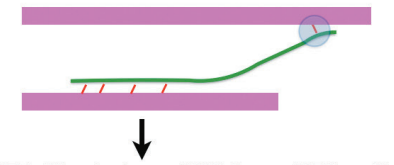

(b) MT-MT bridge by large MAP (loose MT bundle)

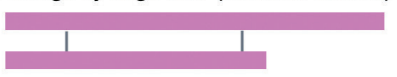

(c) A F-actin bridges two MTs

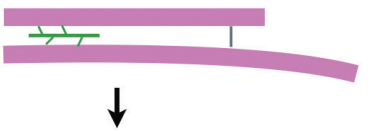

(d) MT-MT bridge by small MAP (tight MT bundle)

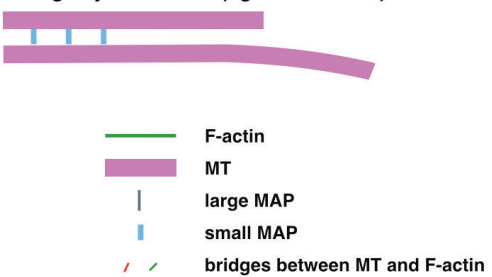

困 8 微小管帯形成におけるF-アクチンの役割. (A) 蛍光抗体法の データ (Eleftheriou and Palevitz 1992, Liu and Palevitz 1992, Takeuchi and Mineyuki 2014) から考えられるアクチンと微小管の関係. 赤, 微 小管 (MT) ; 緑, アクチン. CD, サイトカラシンD. タマネギ根端分 裂組織細胞の PPB (上写真左) とアクチン排除域 (上写真右). サイト カラシン処理した細胞の幅の広くなったPPB (下写真左), それに付 随するアクチン (下写真中央) とその拡大図 (下写真右). (B) タマ ネギ子葉表皮 PPBのトモグラムから抽出した微小管に治つて走るFアクチン (緑矢印). 黒矢印はFアクチンと微小管の架橋構造を示す. Bar $=50 \mathrm{~nm} . \quad$ (C) トモグラム解析データから作成した微小管束化 におけるF-アクチンの役割のモデル. 緑の細い線, F-アクチン; 紫 の太い線, 微小管; 赤と緑の斜め細い線, F-アクチンと微小管との 架橋; 黒の短い線, 長い微小管間架橋; 水色の短い線, 短い微小 管間架橋 ; (Takeuchi ら 未発表). 
アクチン毒のサイトカラシンで微小管幅が狭くなる過程 が阻害されることから，アクチンが微小管帯を狭くする 過程に働いていると考えられている (Mineyuki and Palevitz 1990)。1987年に3つのグループが別々にPPBにアクチ ンが存在すること在報告 (Trass et al. 1987, Palevitz 1987, Kakimoto and Shibaoka 1987) して以降, 蛍光プローブを使つ たPPBのアクチンの研究が多くなされてきた. 図8Aに分 裂組織の細胞におけるアクチンの挙動をまとめた。 G2 期 に出現した幅広微小管帯は, 前期の進行々伴に狭くなる. 最初は微小管帯近傍にアクチンが集まっているが, 前期の 最後になるとアクチンは逆に微小管の存在する場所から PPB以外の細胞表層に移動し, CDZにアクチン排除域 (actin depleted zone) が形成される (Liu and Palevitz 1992, Cleary et al. 1992). サイトカラシンはF-アクチンに結合して重合阻 害を起こすことでF-アクチンの脱重合を誘導するが, 植 物 F-アクチンはサイトカラシン処理で完全には脱重合せず, 切断され短いF-アクチンになる。 PPBへのサイトカラシン 処理では, 微小管帯が狭くなる過程を阻害するだけでなく, すでに幅の狭くなっていた微小管帯も幅が広くなる。この 時, アクチンはPPBから排除されなくなり, むしろ微小管 帯と共局在する様になる (Takeuchi and Mineyuki 2014).

我々は加圧凍結後適当な方法で凍結置換することで, 安 定的にF-アクチン (正確にはマイクロフィラメント) 在電 子顕微鏡で観察できる様になつた (Murata et al. 2002).こ の試料を使い, 電子顕微鏡レベルのCTである電子線卜モ グラフィ一法で観察すると, F-アクチンと思われるマイク ロフィラメントと, マイクロフィラメントと微小管を連結 する構造がはつきりと検出できた（図8B).このデータの 詳細な解析から, 蛍光プローブでアクチンが存在すると言 われている時期には, PPB内にはF-アクチン様構造として, 比較的短いマイクロフィメントが存在していることが分 かった．微小管に沿って1本のF-アクチンが走っている像 がよく観察されるが, その中に片方の端が微小管から離れ 近くの微小管まで伸びている像 (図 $8 \mathrm{C}(\mathrm{a}),(\mathrm{b})$ ) が観察でき た. また，平行して走る2本の微小管の間に1本のF-アク チンが平行に走り, このF-アクチンが両方の微小管に架 橋構造で連結している構造も観察できた(図 $8 \mathrm{C}$ (c), (d)). 前者は少し離れた微小管同士を近づけるのに，後者は長い 架橋構造で結ばれている2本の微小管をより近付けて PPB の最後の時期に現れる短い架橋構造に移行するのに働いて いると考えれば説明がつく。これらのことから，比較的短 いF-アクチンがPPB形成過程での微小管同士の束化に働 いている可能性が考えられる (Takeuchi ら 未発表).

\section{まとめと今後の展望}

我々の研究を中心にPPBの発見から現状までを解説し た. Mineyuki と Gunning が1990年に提案したモデルから 25 年で, PPBの形成とその後のメモリ一蓄積過程に関与 する因子の実体もかなり明らかになり，PPBが形成される 過程で CDZが確立し, 細胞分裂の最後で細胞板の正しい 挿入が行われ，そこで細胞板の成熟が起こるという一連の 過程が分子レベルで大分繋がってきた. PPBは最初微小管 の帯 (preprophase band of microtubule) として発見されたが, 現在ではPPBはCDZ在形成するための細胞質分裂装置と して扱うのが妥当のように思われる．英語ではかなり古く
からPPB はは微小管の帯とその周りの構造や分子を含ん だ細胞分裂を準備する構造として扱わ机ているのに対し， 我が国の文部省学術用語集では“preprophase band”ではな く“preprophase microtubule band”という用語が採用され， 和訳として“前期前微小管束”という言葉が使われている. 1997 年に本誌にこの日本語はPPBの研究の歴史を踏まえ ると不適切な訳語であり “分裂準備帯” と呼ぼうという記 事を書いた. 幸いにして, 私のグループ以外の専門家も最 近は科研費や学会のHPに“分裂準備帯”在使つてくれるよ うになったが，未だに日本を代表する辞典は改まっていな い. 本総説を読んで “preprophase”とは前期の前の時期では ないこと,また, PPBは微小管が束 (bundle) になることが 大事ではなく, 帯状 (band) に並ぶことが大事な事を理解 してもらえれば幸いである。そのうち辞典や教科書にも分 裂準備帯という言葉が使われること祈って筆を置く.

\section{謝辞}

本研究は学生時代から現在まで, 東大古谷研究室, オーストラリア国立大 Gunning 研究室, ジョージア大学 Palevitz 研究室, 広島大学および兵庫県立大学の私の研究 室で行ってきた研究をまとめたものである．私がこれらの 研究室に所属していた時に指導・共同研究をしていただい た学生を含む多くの研究者の方々に謝意を表します. 研究 室でできない研究を共同研究の形で研究させていただいた 国内外の共同研究者に感謝いたします. 後半の電子顕微鏡 の研究では, L. Andrew Staehelin, Thomas Giddings（コロラ ド大学), 村田隆 (基生研), 唐原一郎 (富山大) 博士とその 研究室の皆さんにお世話になりました. また, 竹内美由紀 博士 (東大) は電子線卜モグラフィ一の未発表のデータの 提供を, 薮内隆俊氏 (兵庫県立大) は図 $4 \mathrm{C}$ のデル作製に 協力をいただきました．この2名には最後の原稿にも目を 通していただき感謝しています。

\section{引用文献}

Azimzadeh, J., Nacry, P., Christodoulidou, A., Drevensek, S., Camilleri, C., Amiour, N., Parcy, F., Pastuglia, M., and Bouchez, D. (2008) Arabidopsis TONNEAU1 proteins are essential for preprophase band formation and interact with centrin. Plant Cell 20: 2146-2159.

Burgess, J., and Northcote, D. H. (1969) Action of colchicine and heavy water on the polymerization of microtubules in wheat root meristem. J Cell Sci 5: 433-451.

Busby, C. H., and Gunning, B. E. S. (1980) Observations on pre-prophase bands of microtubules in uniseriate hairs, stomatal complexes of sugar cane, and Cyperus root meristems. Eur J Cell Biol 21: 214223.

Buschmann, H., Chan, J., Sanchez-Pulido, L., Andrade-Navarro, M. A., Doonan, J. H., and Lloyd, C. W. (2006) Microtubule-associated AIR9 recognizes the cortical division site at preprophase and cellplate insertion. Curr Biol 16: 1938-1943.

Camilleri, C., Azimzadeh, J., Pastuglia, M., Bellini, C., Grandjean, O., and Bouchez, D. (2002) The Arabidopsis TONNEAU2 gene encodes a putative novel protein phosphatase $2 \mathrm{~A}$ regulatory subunit essential for the control of the cortical cytoskeleton. Plant Cell 14: 833-845.

Cho, S.-O., and Wick, S. M. (1989) Microtubule orientation during stomatal differentiation in grasses. $J$ Cell Sci 92: 581-594.

Cleary, A. L., and Hardham, A. R. (1989) Microtubule organization during development of stomatal complexes in Lolium rigidum. Protoplasma 149: 67-81.

Cleary, A., Gunning, B. E., Wasteneys, G. O., and Hepler, P. K. (1992) 
Microtubule and F-actin dynamics at the division site in living Tradescantia stamen hair cells. J Cell Sci 103: 977-988.

Colasanti, J., Cho, S.-O., Wick, S., and Sundaresan, V. (1993) Localization of the functional $\mathrm{p} 34^{\text {cdc2 }}$ homolog of maize in root tip and stomatal complex cells: Association with predicted division sites. Plant Cell 5: 1101-1111.

Dhonukshe, P., and Gadella, T. W. J. (2003) Alteration of microtubule dynamic instability during preprophase band formation revealed by yellow fluorescent protein-CLIP170 microtubule plus-end labeling. Plant Cell 15: 597-611.

Duroc, Y., Bouchez, D., and Pastuglia, M. (2011) The preprophase band and division site determination in land plants. In: The Plant Cytoskeleton, Springer, pp 145-185.

Eleftheriou, E. P., and Palevitz, B. A. (1992) The effect of cytochalasin D on preprophase band organization in root tip cells of Allium. J Cell Sci 103: 989-998.

Gunning, B. E. S. (1982) The cytokinetic apparatus: Its development and spatial regulation. In: The Cytoskeleton in Plant Growth and Development., Lloyd, C.W. (ed), Academic Press, London, pp 229292.

Gunning, B. E. S., and Sammut, M. (1990) Rearrangements of microtubules involved in establishing cell division planes start immediately after DNA synthesis and are completed just before mitosis. Plant Cell 2: 1273-1282.

Harris, H. (1999) The birth of the cell. Yale University Press, New Haven, London.

Hofmeister, W. I. (1849) Die Entstehung des Embryo der Phanerogamen: eine reihe mikroskopischer Untersuchungen, Hofmeister.

Hush, J. M., Wadsworth, P., Callaham, D. A., and Hepler, P. K. (1994) Quantification of microtubule dynamics in living plant cells using fluorescence redistribution after photobleaching. J Cell Sci 107: 775784.

Hush, J. M., Wu, L., John, P. C. L., Hepler, L. H., and Hepler, P. K. (1996) Plant mitosis promoting factor disassembles the microtubule preprophase band and accelerates prophase progression in Tradescantia. Cell Biol Int 20: 275-287.

Kamimoto, T., and Shibaoka, H. (1987) Actin filaments and microtubules in the preprophase band and phragmoplast of tobacco cells. Protoplasma 140: 151-156.

Karahara, I., Suda, J., Tahara, H., Yokota, E., Shimmen, T., Misaki, K., Yonemura, S., Staehelin, L. A., and Mineyuki, Y. (2009) The preprophase band is a localized center of clathrin-mediated endocytosis in late prophase cells of the onion cotyledon epidermis. Plant J 57: 819-831.

Karahara, I., Staehelin, L. A., and Mineyuki, Y. (2010) A role of endocytosis in plant cytokinesis. Comm Int Biol 3: 36-38.

Karahara, I., Staehelin, L. A., and Mineyuki, Y. (2012) The role of endocytosis in the creation of the cortical division zone in plants, In: Ceresa, B. (ed) Molecular regulation of endocytosis. INTECH Open Access Publisher, pp 41-60.

Lipka, E., Gadeyne, A., Stöckle, D., Zimmermann, S., De Jaeger, G., Ehrhardt, D. W., Kirik, V., Van Damme, D., and Müller, S. (2014) The phragmoplast-orienting kinesin-12 class proteins translate the positional information of the preprophase band to establish the cortical division zone in Arabidopsis thaliana. Plant Cell 26: 26172632.

Liu, B., and Palevitz, B. A. (1992) Organization of cortical microfilaments in dividing root cells. Cell Motil Cytoskel 23: 252-264.

Lyndon, R. F. (1990) Plant Development: The cellular basis, Unwin Hyman, London.

Marc, J., and Hackett, W. P. (1989) A new method for immunofluorescent localization of microtubules in surface cell layers. Application to the shoot apical meristem of Hedera. Protoplasma 148: 70-79.

McClinton, R. S., and Sung, Z. R. (1997) Organization of cortical microtubules at the plasma membrane in Arabidopsis. Planta 201: 252-260.

Mineyuki, Y., and Gunning, B. E. S. (1988) Streak time-lapse video microscopy - analysis of protoplasmic motility and cell division in
Tradescantia stamen hair cells. J Microsc 150: 41-55.

Mineyuki, Y., Marc, J., and Palevitz, B. A. (1988a) Formation of the oblique spindle in dividing guard mother cells of Allium. Protoplasma 147: 200-203.

Mineyuki, Y., Wick, S. M., and Gunning, B. E. S. (1988b) Preprophase bands of microtubules and the cell cycle: Kinetics and experimental uncoupling of their formation from the nuclear cycle in onion roottip cells. Planta 174: 518-526.

Mineyuki, Y., Marc, J., and Palevitz, B. A. (1989) Development of the preprophase band from random cytoplasmic microtubules in guard mother cells of Allium cepa L. Planta 178: 291-296.

Mineyuki, Y., and Gunning, B. E. S. (1990) A role for preprophase bands of microtubules in maturation of new cell-walls, and a general proposal on the function of preprophase band sites in cell division in higher plants. J Cell Sci 97: 527-537.

Mineyuki, Y., and Palevitz, B. A. (1990) Relationship between preprophase band organization, F-actin and the division site in Allium. Fluorescence and morphometric studies on cytochalasintreated cells. J Cell Sci 97: 283-295.

Mineyuki, Y., Marc, J., and Palevitz, B. A. (1991a) Relationship between the preprophase band, nucleus and spindle in dividing Allium cotyledon cells. J Plant Physiol 138: 640-649.

Mineyuki, Y., Yamashita, M., and Nagahama, Y. (1991b) p $34^{\mathrm{cdc} 2}$ kinase homologue in the preprophase band. Protoplasma 162: 182-186.

Mineyuki, Y., Iida, H., and Anraku, Y. (1994) Loss of microtubules in the interphase cells of onion (Allium cepa $\mathrm{L}$.) root tips from the cell cortex and their appearance in the cytoplasm after treatment with cycloheximide. Plant Physiol 104: 281-284.

Mineyuki, Y. (1999) The preprophase band of microtubules: its function as a cytokinetic apparatus in higher plants. Int Rev Cytology 187: $1-49$.

峰雪芳宣 (1997) Preprophase band の訳語について. Plant Morphol 9: 65-67.

峰雪芳宣, 唐原一郎, 村田隆, Otegui, M., Giddings, H. T., Staehelin, L. A. (2001) 植物組織の高圧 (加圧) 凍結. 電子顕微鏡 36: 105-107.

峰雪芳宣, 須田甚将, 唐原一郎 (2004) 電子線卜モグラフィー. Plant Morphol 16: 21-30.

Müller, S., Han, S., and Smith, L. G. (2006) Two kinesins are involved in the spatial control of cytokinesis in Arabidopsis thaliana. Curr Biol 16: $888-894$

Mullinax, J. B., and Palevitz, B. A. (1989) Microtubule reorganization accompanying preprophase band formation in guard mother cells of Avena sativa L. Protoplasma 149: 89-94.

Murata, T., Karahara, I., Kozuka, T., Giddings, T. H., Staehelin, L. A., and Mineyuki, Y. (2002) Improved method for visualizing coated pits, microfilaments, and microtubules in cryofixed and freeze-substituted plant cells. J Electron Microsc 51: 133-136.

Nogami, A., Suzaki, T., Shigenaka, Y., Nagahama, Y., and Mineyuki, Y. (1996) Effects of cycloheximide on preprophase bands and prophase spindles in onion (Allium cepa L.) root tip cells. Protoplasma 192: 109-121.

Ôta, T. (1961) The role of cytoplasm in cytokinesis of plant cells. Cytologia 26: 428-447.

Packard, M. J., and Stack, S. M. (1976) The preprophase band: possible involvement in the formation of the cell wall. J Cell Sci 22: 403-411.

Palevitz, B. A., and Hepler, P. K. (1974) The control of the plane of division during stomatal differentiation in Allium. I. Spindle reorientation. Chromosoma 46: 297-326.

Palevitz, B. A. (1987) Actin in the preprophase band of Allium cepa. $J$ Cell Biol 104: 1515-1519.

Pickett-Heaps, J. D., and Northcote, D. H. (1966a) Organization of microtubles and endoplasmic reticulum during mitosis and cytokinesis in wheat meristems. J Cell Sci 1: 109-120.

Pickett-Heaps, J. D., and Northcote, D. H. (1966b) Cell division in the formation of the stomatal complex of the young leaves of wheat. $J$ Cell Sci 1: 121-128.

Pickett-Heaps, J. D. (1969) Preprophase microtubule bands in some abnormal mitotic cells of wheat. $J$ Cell Sci 4: 397-420. 
Pietra, S., Gustavsson, A., Kiefer, C., Kalmbach, L., Hörstedt, P., Ikeda, Y., Stepanova, A. N., Alonso, J. M., and Grebe, M. (2013) Arabidopsis SABRE and CLASP interact to stabilize cell division plane orientation and planar polarity. Nat Commun 4: 2779.

Rasmussen, C. G., Wright, A. J., and Müller, S. (2013) The role of the cytoskeleton and associated proteins in determination of the plant cell division plane. Plant $J$ 75: 258-269.

Spinner, L., Gadeyne, A., Belcram, K., Goussot, M., Moison, M., Duroc, Y., Eeckhout, D., De Winne, N., Schaefer, E., and Van De Slijke, E. (2013) A protein phosphatase 2A complex spatially controls plant cell division. Nat Commun 4: 1863.

Strasburger, E. (1880) Zellbildung und Zelltheilung, $3^{\text {rd }}$ ed, Fischer, Jena

Takeuchi, M., and Mineyuki, Y. (2014) Actin-microtubule interaction during preprophase band formation in onion rot tips visualized by immunofluorescence microscopy. In: Atlas of Plant Cell Structure, Tetsuko, N., Kawano, S., Tsukaya, H., Matsunaga, S., Sakai, A., karahara, I., Hayashi, Y. (eds), Springer Japan, Tokyo, pp 132-133.

Traas, J. A., Doonan, J. H., Rawlins, D. J., Shaw, P. J., Watts, J., and Lloyd, C. W. (1987) An actin network is present in the cytoplasm throughout the cell cycle of carrot cells and associates with the dividing nucleus. J Cell Biol 105: 387-395.

Traas, J., Bellini, C., Nacry, P., Kronenberger, J., Bouchez, D., and Caboche, M. (1995) Normal differentiation patterns in plants lacking microtubular preprophase bands. Nature 135: 676-677.

Van Damme, D., Coutuer, S., De Rycke, R., Bouget, F.-Y., Inzé, D., and Geelen, D. (2006) Somatic cytokinesis and pollen maturation in Arabidopsis depend on TPLATE, which has domains similar to coat proteins. Plant Cell 18: 3502-3518.

Van Damme, D., Gadeyne, A., Vanstraelen, M., Inzé, D., Van Montagu, M. C., De Jaeger, G., Russinova, E., and Geelen, D. (2010) Adaptinlike protein TPLATE and clathrin recruitment during plant somatic cytokinesis occurs via two distinct pathways. Proc Natl Acad Sci USA: 108: 615-620.

Vanstraelen, M., Van Damme, D., De Rycke, R., Mylle, E., Inzé, D., and Geelen, D. (2006) Cell cycle-dependent targeting of a kinesin at the plasma membrane demarcates the division site in plant cells. Curr Biol 16: 308-314.

Venverloo, C. J. (1990) Regulation of the plane of cell division in vacuolated cells. II. Wound-induced changes. Protoplasma 155: 8594.

Vos, J. W., Dogterom, M., and Emons, A. M. C. (2004) Microtubules become more dynamic but not shorter during preprophase band formation: A possible "search-and-capture" mechanism for microtubule translocation. Cell Motil Cytoskel 57: 246-258.

Wada, M., Mineyuki, Y., Kadota, A., and Furuya, M. (1980) The changes of nuclear position and distribution of circumferentially aligned cortical microtubules during the progression of cell cycle in Adiantum protonemata. Bot Mag (Tokyo) 93: 237-245.

Walker, K. L., Müller, S., Moss, D., Ehrhardt, D. W., and Smith, L. G. (2007) Arabidopsis TANGLED identifies the division plane throughout mitosis and cytokinesis. Curr Biol 17: 1827-1836.

Wick, S. M., and Duniec, J. (1983) Immunofluorescence microscopy of tubulin and microtubule arrays in plant cells. I. Pre-prophase band development and concomitant appearance of nuclear envelopeassociated tubulin. J Cell Biol 97: 235-243.

Wick, S. M., and Duniec, J. (1984) Immunofluorescence microscopy of tubulin and microtubule arrays in plant cells. II. Transition between the pre-prophase band and the mitotic spindle. Protoplasma 122: 4555

Wright, A. J., Gallagher, K., and Smith, L. G. (2009) discordial and alternative discordial function redundantly at the cortical division site to promote preprophase band formation and orient division planes in maize. Plant Cell 21: 234-247.

Wu, S.-Z., and Bezanilla, M. (2014) Myosin VIII associates with microtubule ends and together with actin plays a role in guiding plant cell division, eLIFE 3:e03498 DOI:10.7554.

Xu, X. M., Zhao, Q., Rodrigo-Peiris, T., Brkljacic, J., He, C. S., Müller, S., and Meier, I. (2008) RanGAP1 is a continuous marker of the
Arabidopsis cell division plane. Proc Natl Acad Sci USA 105: 1863718642.

Received: 18 February 2015 / Accepted: 11 March 2015 